\title{
Motivations and Emotions Behind Guru Seeking: A Case Study of Thakur Anukulchandra in Bhubaneswar, Odisha
}

Article Info

Received: 8 May, 2021

Received in revised form: 13 December, 2021

Accepted: 15 December, 2021

Available online: 30 December, 2021

DOI: $\underline{\text { https://doi.org/10.3126/dsaj.v15i01.41927 }}$
Soumya Mohapatra

Kalinga Institute of Industrial Technology, India

This article explores why people seek out a religious guru, with special reference to Thakur Anukulchandra and his followers in contemporary urban settings of Bhubaneswar, Odisha in India. Through an ethnographic approach, this article examines the expectations of the devotees while seeking out spirituality and what kind of emotions people go through in this process, i.e. their hopes, disappointments, social bonds created with the guru and other followers. It looks at why the followers of this tradition are attracted to this particular ideology, philosophy and its relevance in an urbane setting. The study's rationale is to explore the complex emotional bond between the guru and the followers, the narratives of devotion, accounts of miracles performed, indices of anxiety, and the nature of well-being. Findings suggest that Thakur's sect provides people with a meaning and purpose in life and a personal connection with the charismatic guru that helps them tide over various existential crises. By making connections between the past and the present, the organization tries to anchor people's lives and experiences.

Keywords: charisma, guru seeking, motivations, socially-mediated emotions, satsang

\section{Introduction}

Gurus, or spiritual guides, have always been revered in Hindu society for their wisdom and knowledge. Traditionally, the guru was an ascetic teacher belonging to the priestly or Brahmin caste who derived his authority from his enviable knowledge of the sacred scriptures and was believed to be the repository of all spiritual wisdom. It was customary for people from the privileged sections of society to spend a good part of their childhood at the guru's house known as 'gurukul'. The phenomenon of guruship has been a classic and persistent theme within South Asian scholarship, especially how the guru, as a charismatic figure, continues to enchant a large number of people providing them a meaning in life (Copeman and Ikegame, 2012; Pandya, 2016; Pandya, 2019). The present-day Hinduism is witnessing a sharp rise in high-profile organizations led by charismatic gurus. As observed by Warrier (2003), the more thriving the guru-based organization, the more its reach is, heading large 'institutional empires', which are financed by very liberal amounts of donations, from amongst thousands of prosperous devotees, both in India and overseas.

This study explores the case of Thakur Anukulchandra and his followers in Bhubaneswar city of Odisha in India to examine and understand the emotions and motivations behind guru-seeking in a contemporary urban context. Born to Sivachandra Chakravarty and Monmohini Devi, in Himaitpur village of Pabna District of British India (now in Bangladesh), Thakur was named Anukulchandra Chakravarty at birth (Hauserman, 1962). Thakur Anukulchandra (1888-1969) was a doctor who later became a religious guru and founded the Satsang Ashram. The registration of the Satsang was originally done in Pabna, Bangladesh in 1925 as a public charitable institution. After India was partitioned, the Satsang was registered in the 
Indian Union in 1951. Thakur Anukulchandra left Pabna for Deoghar, (the organization's headquarter situated in present-day Jharkhand) in 1946. More than two thousand branches of the Satsang are located across India, Myanmar, Europe, America, and Bangladesh. This article is based on the qualitative research carried out primarily in the Satsang Temple in Bhubaneswar.

\section{Research Method}

This study is primarily qualitative and fieldwork was conducted in the Satsang located at Bhubaneswar between the years 2015-2017. It utilized primary and secondary sources of data. In-depth interviews were conducted with devotees and participant observation and informal interviews. The followers of Thakur Anukulchandra, where fieldwork was conducted, are mostly urban residents engaged in white-collar occupations. Many of them are engaged in professions that are considered more 'prestigious'. These devotees include, among others, government officials, doctors, teachers, lawyers, college lecturers, journalists, managers in multinational corporations or in smaller private sector companies, engineers, and scientists. Most of these people have been educated in well-known educational institutions and even their children are studying in prominent schools, colleges, and universities. Snowball sampling technique was used to locate new and old devotees and followers

Additionally, the respondents included Thakur's devotees and the temple administrators, which provided additional insights into the Satsang activity. The units of analysis were the individuals, the organization, and social artifacts such as newsletters, books, magazines. Along with this, regular field visits were done to participate in the organization's cultural events and spiritual lectures.

Analysis of religious and other publicity material has been used to explore the issues of representation of charisma and guru devotion. These materials include Thakur Anukulchandra's works, official biographies, published and unpublished works of disciples, messages, conversations, and interviews were recorded, transcribed, and analyzed.

My approach in this work has been ethnographic. Through observation, I sought to understand religious phenomena by observing and reflecting on what people do. The focus was mostly on observable activities, actual events and practice, along with what texts, preachers, or even 'ordinary' participants assert people ought to do. A survey questionnaire was prepared and basic information of about 120 devotees was gathered regarding their socioeconomic details and their association with the Satsang. Based on the information, 48 in-depth interviews were conducted. The interviews were semi-structured. They started with specific themes and issues but remained open for new questions to come up. This opened a window to understand and interpret people's thoughts, beliefs, ideas and conceptions. To supplement my understanding of Thakur and his teachings, hagiographies and biographies written by devotees have been extensively used. The choice of using these as the source material is because these works offer access into the social situations which are not directly observable anymore, i.e., the intimate conversations and interactions of the charismatic guru with his followers during different periods of his life and career.

The Satsang Vihar where fieldwork was conducted is located in Bhubaneswar along the National Highway 5 (Kolkata-Chennai). The huge, all-white temple is situated four kilometers from the railway station and ten kilometers from the Bhubaneswar airport. Even though many temples in Odisha have been made in the name of Thakur, the one in Bhubaneswar is the largest with a huge number of followers.

\section{Findings}

\section{The Charismatic Power of Thakur and Devotees' Motivations}

Scholars have noted a variety of reasons why individuals seek guru and follow them. Individuals often seek guru based on their personal power and charisma typical to them. Warrier (2003) notes that even though individual gurus have their own personal styles of preaching and recommend different modes of approaching the divine, some elements are typical to all of them and thus, certain commonalities may be derived. Firstly, the gurus are revered as spiritually enlightened people. From the perspective of a devotee, the gurus can make his/her devotees lead happy and contented lives through their special powers. Another important factor that has a huge potential of attracting devotees into a spiritual order is the perception of the guru as a miracle worker.

A personal attachment with the guru and some degree of fellow-feeling with the community of followers is generally observed in most guru-based organizations. Such kind of intimate ties are mostly maintained not through the bases of daily conversations and interactions amongst the devotees but by perpetuating the narrative that idealizes the guru as being 'omniscient', 'omnipresent' and 'omnipotent.' These narratives create a sense of the guru's constant presence in the daily lives of his/her followers, guiding them towards well-being. An important role is also played by how the guru-organizations use mass media to reach out to the devotees in any corner of the world e.g. audio and video recordings of the guru's activities, online availability of sacred books, and newsletters about the activities of the organization.

Participation in such devotional organizations commonly requires a devotee to practice the daily ritual of worshipping the guru, meditation, being a part of rituals such as bhajan (devotional songs having religious themes), kirtan (devotional singing), and sermons organized by the mandir or neighborhood committees and sometimes 
going to the guru's headquarters. During such rituals, the expression of each individual sentiment spurs a gradual boost in the collective sentiment of experiencing a sacred power together. Through the experience of this synergistic emotion, individuals unite as a group. Therefore, for Durkheim sentiments become real and trustworthy only if they are collectively felt and confirmed (Durkheim et al., 2001).

The present-day Bhubaneswar's makeup varied with Buddhism, Jainism, Shaivism and Vaishnavism, which found an abode in the city during different times, with the changing dynasties of Kalinga (the ancient name for Odisha). All these religions gave Bhubaneswar its present sacred character (Kalia, 1994). Today in Bhubaneswar, the devotees of Thakur Anukulchandra come from various walks of life. They are mostly urbanites working in the services sector. Therefore, these people have esteemed jobs, are well-off, and have access to modern goods and services. However, in contemporary times, this urban middle class is dealing with issues of alienation, lack of a sense of community or meaning in life. This is where guru-based organizations come in to provide people with a refuge against the impersonal organizations of the modern urban environment. For example, a devotee of Thakur explains:

This is a platform where one can learn the art of maintaining balance in one's life- personal, familial, social. Without a guru life is meaningless. Shivaji had Ramdas, Chandragupta Maurya had Chanakya, Arjuna had Sri Krishna... likewise, mine is Thakur.

Guru-based organizations provide individuals with a structure in life by invoking the past that was supposedly 'simple but meaningful', giving individuals the capacity to face the uncertainties of a modern, city-life. They help the individual in finding the 'ultimate truth' and give anchor to a devotee's life. By sharing a common philosophy of life and a network of relationships, these spiritual organizations provide stability, discipline, and meaning in devotees' lives and address problems encountered by the urban middle class. As religion is widely considered a cure for existential crises, it could be attributed to the surge in religious intensity among certain sections of society. Given the power of religion in effectively addressing the many problems tormenting India's urban population, the intensified religiosity among people is natural.

\section{Making 'Sense' of Life}

In many cases, people feel that something 'personal' and 'meaningful' was missing in their everyday professional interactions. This was when they felt that a guru would provide them some respite, hope and faith. Many devotees who were in distress also came to know about Thakur Anukulchandra through the extended family members, neighbors, friends who insisted that they go to the satsang ashram get a 'feel of the ambiance' and seek the blessings of the guru, practice his spiritual recommendations, attend sermons and see if it made any kind of difference in their lives. News of Thakur that appeared in popular media was also a means through which the devotees came to know of him. So, the reasons for becoming a devotee are myriad and are dependent upon the social circumstances of the devotee. For example, according to a female devotee, aged 49 who has been working for Thakur's ashram for 20 years explained:

Thakurji is not only a guru for me; he is an incarnation of god. During the birth of my third daughter, I developed some medical complications and was very critical...almost on my death bed. I recovered only through the grace of Thakurji. After this incident, I have made the Satsang Vihar my home. Even my husband left his job to be with me here. Now I serve the Thakur every moment.

Another devotee, who has been initiated since the last 15 years, reported:

I was very depressed as my daughter was estranged from me. My neighbor, who is a devotee of Thakur $\mathrm{ji}$, asked me to join his family in prayer. While I was doing kirtan, I saw the guru blessing my daughter. When I came back home, I felt strangely relaxed. In a few days, miraculously, my daughter returned. I have been a disciple ever since.

The devotees are generally required to travel to the headquarters after they take initiation in order to seek blessings of the guru or visit him/her when they come to the city. This provides the devotees with assurance and security of being a part of something greater than themselves, provides a feeling of kinship and togetherness and the belief that they are in the presence of magical, marvelous power. Many devotees explain this experience as a kind of being 'overwhelmed as well as unburdened' after which they feel 'free'. Thus, the question arises, how can one make sense of these religious emotions which the devotees feel?

According to Durkheim religious emotion, sentiment is a byproduct of religion and society at large. By participating in collective rituals and beliefs, an individual can experience intense emotions and the overwhelming power of the social. Therefore, for Durkheim, powerful emotions can only be felt in the company of a collective, in gatherings rather than in solitude. He also says that 'collective effervescence' or ecstasy can be felt only when a group of people comes together and where the individual gets dissolved in the collective (Durkheim et al., 2001).

When individuals or objects are considered to have charisma, others view them with the emotions of awe, fear, and enthusiasm. It is something that is sacred and is not to be trivialized. In this case, the relationship between a charismatic person (Thakur Anukulchandra) and his disciples is mostly based on emotions. Weber (1964) argues that charisma can be observed in two ways. Firstly, charisma can be viewed as a special gift that sets 
an individual apart from mundane, everyday things, and secondly, charisma also has a social angle wherein it is conferred on the leader by his or her followers who see in the person some special kind of power and try to become a part of it through participation.

While trying to participate in the guru's powers, individuals feel that they are in the presence of an allpervading power, that there is someone to protect and heal them. Devotees surrender to the guru, thinking that $\mathrm{s} / \mathrm{he}$ can control or change their destiny. Often, the devotees themselves let go of a sense of control from their daily lives and instead get acquainted with an alternative outlook in which the guru is seen as a divine manager who knows what is best for the devotees and thus, controls their lives. As a 55-year-old devotee of Thakur Anukulchandra explains:

Earlier I used to get worked up for trivial things.

Domestic issues, problems at the office bothered me a lot. After getting initiation and reading Thakur's philosophy, I have become calmer. Things do not bother me the way they used to earlier. Now I understand that these problems are not my own. They have been created by Thakur for some reason and will be solved by him.

In some cases, devotees seek out a particular guru because of expectations that they will be benefitted materially. In other cases, devotees search for more non-material, spiritual rewards. Devotees who are on the lookout for spiritual benefits hope that by following Thakur Anukulchandra's prescriptions in their lives, they would 'mature' spiritually. For example, Basanti Swain, a 47-year-old devotee and a businesswoman by profession explain, belief in gurus has been present in India since ancient times. It is the only way through one can know the right path and this will help in all-around development, personal, physical, mental and spiritual." This statement reveals how important culture and symbols are for understanding religious emotion. In order to comprehend religious emotion, it is important to understand it holistically by analyzing its cultural and symbolic characteristics and then connecting it to the religious and social experiences of the devotees. Geertz (1971), in his essay ' religion as a cultural system', puts 'emotion' at the heart of his narrative of religion. In his essay, he highlights a few of the characteristics and most significant elements of religious emotion. According to him, religion is:

(1) a system of symbols (2) which acts to establish powerful, pervasive and long-lasting moods and motivations in men (3) by formulating a conception of a general order of existence and (4) clothing these conceptions with such an aura of factuality that (5) the moods and motivations seem uniquely realistic. (Geertz 1971: 4)

This definition given by Geertz describes what religious emotion is and its wide scope. Individuals are often able to describe a feeling or sense of passion during a religious event, even though they cannot name that feeling. Therefore, religious emotions leave a lasting impression in the minds of individuals besides serving as a form of motivation.

The devotees of Thakur Anukulchandra view him as someone who will fulfill their wishes and desires. He is also perceived as an extraordinary man whose whole life is an ideal example of how the disciples can lead their lives. When faced with existential crises, individuals question the purpose of their being and often find life meaningless. In such a scenario, they wish to resort to a life that has been explicated by the spiritual guide or 'Thakur' so that they feel a sense of fulfillment in a material sense apart from hoping to reap spiritual benefits. So, in most of the cases, the devotees' motivations in attaching themselves to Thakur and the Satsang are a blend of the two things.

Sometimes, devotees might be on the lookout of physical or material rewards along with the pursuit of spiritual meaning in their lives. A 30-year-old female devotee, a doctor by profession, described an incident about her grandfather's experience with Thakur. She said:

I have heard this story from my father. My grandfather had lost his job. Even after trying very hard to get another job, he could not find one. He was constantly anxious and irritable. Our financial condition took a turn for the worse. One day, our neighbor, a devotee of Thakurji asked our family to accompany them to Deoghar and meet him. On meeting Thakurji, my grandfather offered him a gold ring as a token of his affection. Thakurji said he had accepted my father's affections and returned the ring, saying that he was gifting it back and everything would get well soon. Within two weeks of our return, my grandfather found employment, and since that time, our family has been disciples of Thakurji. We were able to find financial security and peace in our lives due to his blessings.

As the narrative above shows, devotees might find meaningfulness in material and spiritual terms, and these two things need not be in opposition to each other.

\section{Relationship Among Thakur, the Satsang and His Devotees}

The reasons for seeking out a guru are varied, and all devotees might not think in the same terms. Even within the circle of devotees, sometimes, a hierarchical relationship can be carved out between those devotees who approach the guru for material reasons instead of those who claim to have spiritual reasons for seeking out the guru. The devotees who say they sought out the guru for purely spiritual reasons are inclined to view others who are more concerned with wish-fulfillment or seeking material benefits as not fully mature in a spiritual sense. As a devotee explained:

I agree that all of the people here who claim to be 
the devotees of Thakur might not be so in the real sense. However, we can know who is a real devotee and who is not. For example, you will find many people in business who have joined the satsang solely to strengthen their business networks. There are a few politicians who treat us like vote banks. However, someday, they will realize what Thakur's ideology stands for. Money will be a by-product when your intentions are pure and you work hard. So there is no need to chase it.

For some devotees, the knowledge of the 'right' guru is akin to an instinctive awareness that cannot be fully explained through words. A devotee of Thakur described how he had been feeling low and was not getting any motivation from his family or the society at large. In order to understand himself, he wanted the guidance of a guru, and during the course of his search, he had got acquainted with a number of gurus and their organizations, but he found none of them up to the mark. It was when he attended an event that was taking place in his neighborhood that he became attached to Anukulchandra at the time that he finally felt he could 'surrender' himself to him, and this too did not happen at the first meeting but after several such meetings and trips to the Satsang. He opined that in his case, there was no rationale to how he felt about Thakur; it was the 'positive vibes' that he could 'feel within himself that made him choose Thakur.

Another significant characteristic that the devotees use to choose a guru of their liking is how the guru delivers religious discourses. Sometimes, it is the simple and spontaneous message with regards to gurus like the teachers of the Thakur Anukulchandra faith today, which holds the devotees' imaginations with their simple stories, anecdotes, and parables. Teachers and leaders of the Anukulchandra faith, for instance, convey his teachings, philosophy of life, and practices in a straightforward manner, mostly avoiding complex Sanskrit terms and abstract conceptions that are generally found in the spiritual discourses by other gurus. A devotee of Thakur who was charmed by the simplicity of his messages explained,

The Satsang, here, provides a positive environment for spiritual growth. Thakur's messages have clarity, which I have not found elsewhere. His main objective is the reformation of society through one's self, to grow upward and help others achieve the same. When we are reformed, people associated with us will see this transformation and want to change for the better. This thought of Thakur attracted me to him.

Another crucial feature of religious emotion that Geertz (1971) argues of is when he describes them as having 'powerful, pervasive and long-lasting moods and motivations. As per Geertz's definition, the idea of 'motivation' also includes the many ways in which religious emotion enables or encourages action by guiding it and sometimes by preventing certain actions. Geertz (1971) says this motivation is wide in scope, in addition to being 'powerful.' A similar kind of emotion is described by a devotee of Thakur Anukulchandra who explains:

I have been a devotee of Thakur for the last five years...earlier, I was very hot-tempered. It was affecting my personal as well as professional life. One of my distant relatives took me along with him to a neighbourhood programme on Thakur one day. I liked the ambiance of the place, the bhajan, kirtan; everything was seemingly ordinary but still had a great feel about it. I started learning more about Thakur by reading the satsang's literature. I realized that my attitude was preventing me from evolving as a person. I got diksha (initiation) and almost immediately felt like a better person. It has made me calmer and stress-free and most importantly, my relationships with others have improved.

What makes the devotees devote themselves wholeheartedly to the guru? It is mostly the experience of a miracle. This experience of an unbelievable, surreal event or event is mainly felt when the individual is inducted into the guru's organization and may continue long after one is initiated into the faith. A 75-year-old devotee, who has been initiated for twenty years, shared his experience of Thakur's power. He said:

In the year 1995, I went on a trip to Deoghar to see the ashram during Durga puja (Thakur's spiritual headquarter) on a whim. I was not a devotee then. I stayed there for a day. While coming back, there was a lot of rush in the trains and was stranded in the station for several hours. There was a stampede-like situation. Suddenly, a fight broke out among some people and all began to run helter-skelter. I was terrified at that time. I started praying to Thakur and somehow, it calmed me down, and I could return home safely. I have been suffering from diabetes for the last thirty years, have been operated on five times, but somehow I have survived till now. I feel that this is due to Thakur's grace.

Another devotee, a 65-year-old retired government employee added, in a similar vein:

I have been a member of the Satsang for thirty years. I first heard about Thakur through an office colleague. In those days, I was not keeping well. I had chronic health problems. When one health issue came under control, another would crop up. Medicines were not working in my case. However, after joining the Satsang, my health improved. Medicines couldn't do what Thakur's blessings did. Even to this day, I meditate for two hours every day, I even advise my friends and relatives to join the Satsang. Earlier, I felt a void in my life, but now I can certainly feel a divine presence. 
It was also interesting to meet a couple of devotees of Thakur Anukulchandra who were on the verge of getting disenchanted from his faith. A 53-year-old woman devotee said she joined the satsang out of baadhyata (compulsion or force). She said:

My neighbor and her whole family are devoted satsangis. They sometimes hold bhajan, kirtan and satsang at their home. They had invited me a couple of times...so one day I went to attend the satsang. A gurubhai from the satsang had come to their home. When my neighbor told him that I was not a devotee, he forced me to join. He said that all the problems in my life would be solved. Even though I rejected his offer initially, he was persistent. Finally, I gave in and took initiation. I thought it would be good for me to be a little more dharmic (spiritual). But all my problems still persist...in fact, they have increased. Recently, I have been diagnosed with arthritis. Both my sons are graduates but unemployed. I am not sure how much longer I will continue to come here.

\section{Conclusion}

The emotional experiences and social sentiments that the devotees experience are closely related. Through socialization processes, members of the community are predisposed to have certain emotional experiences, identify appropriate emotions, and internalize norms for expression in certain situations. The community prepares its members for certain experiences by forming social contexts that inspire these feelings and orchestrating their acts.

Feelings are social acts as well as personal ones. They are performed in direct or indirect interaction with other people, leading to immediate or delayed emotional reactions. The actor and the audience can read expressions of sorrow, joy, tension, awe, disgust, hatred, and anxiety. Such emotions form a basic element in social interaction. A religious setting may allow people to feel and express emotions suppressed in everyday life, help people redefine or redirect their social emotions, or support and sustain the acceptable emotional norms of the wider community.

At times, charismatic authority or leadership in which authority is dictated by charisma may go hand in hand with other types of authority, and they may even complement each other, including within religious communities (Miller, 2003). Individuals share limitations and opportunities in education, employment, social relationships, other opportunities, and resources. What makes them different is their unique stories of struggles and successes and the avenues (or the lack of it) for empowerment. Due to dissimilarities in their social conditioning and value systems, people have to pick and choose their commitments, identities, and priorities. However, along with these different stories, some emotions are associated with and around the charisma of the guru, and these sentiments, in turn, become socially meaningful as they connect people in a social bond wherein they feel for and empathize with each other, 'reorient' themselves in a spiritual community that gives them a sense of 'center' (Juergensmeyer, 1991). Furthermore, a feeling of being a part of something greater than themselves, of belongingness with the same community of believers, is strengthened and reinforced through these emotions.

\section{Acknowledgment:}

This paper is a part of my $\mathrm{Ph} . \mathrm{D}$. thesis titled 'Representation of Charisma and Formation of Religious Community: A Study of Thakur Anukulchandra and his Devotees in Bhubaneswar'. I am grateful to Prof. Susan Visvanathan for her supervision during my Ph.D. and helping me shaping ideas for this paper. I express my gratitude to Dr. Ishwari Bhattarai and Ms. Shilpi Sampad for their perceptive observations on the paper. I would like to thank both the anonymous reviewers who provided their insightful comments and suggestions and the and the copy editors for their careful editing of the manuscript. Finally, I would like to thank Dr. Man Bahadur Khattri, Editor-inChief of the journal, and his team for their help in giving final shape to this paper.

\section{Funding:}

No funding was received for this paper.

\section{Conflict of interest:}

There is no conflict of interest with any individual and agency.

\section{Ethical conduct of research:}

I declare that this research has been conducted ethically.

\section{References}

Copeman, J., \& Ikegame, A. (Eds.). (2012). The guru in south Asia: New interdisciplinary perspectives. Routledge.

Durkheim, E., Cosman, C., \& Cladis, M. S. (2001). The elementary forms of religious life. Oxford University Press.

Das, Prafulla K. (1977). An integral philosophy of life. Satsang Publishing House.

Geertz, C. (1971). Religion as a cultural system. Michael Banton (Ed.), Anthropological approaches to the study of religion. 1-43. Tavistock Publications.

Juergensmeyer, M. (1991). Radhasoami reality: The logic of a modern faith. Princeton University Press.

Kalia, R. (1994). Bhubaneswar: From a temple town to a capital city. Southern Illinois University Press.

Hauserman, R. A. (1962). Ocean in a teacup. Harper \& Brothers.

Miller, J. (2003). Missionary zeal and institutional control: organizational contradictions in the basel mission on 
the gold coast, 1828-1917. Grand Rapids.

Pandya, S. P. (2019). Guru agency: Combining charisma, teachings, and proliferation. In Faith movements and social transformation (pp. 35-60). Springer.

Pandya, S. P. (2016). 'Guru' culture in south Asia: The case of chinmaya mission in India. Society and Culture in South Asia, 2(2), 204-232.

Warrier, M. (2005). Hindu selves in a modern world: Guru faith in the mata amritanandamayi mission. Routledge.

Warrier, M. (2003). Processes of secularization in contemporary India: Guru faith in the mata amritanandamayi mission. Modern Asian Studies, 37, 213-253.

Weber, M. (1964). The theory of social and economic organization. A. M. Henderson and T. Parsons (Trans.) The Free Press.

Soumya Mohapatra https://orcid.org/0000-0003-39841563 is Assistant Professor of Sociology in the School of Law, Kalinga Institute of Industrial Technology (Deemedto-be-University) in Bhubaneswar, Odisha. She holds $\mathrm{Ph} . \mathrm{D}$. from Jawaharlal Nehru University, India. Her interest areas include Sociology of Religion, Sociology of Gender, Migration Studies.

Email: soumya.mohapatra@kls.ac.in 